$$
\text { Find }
$$

\title{
Technology and Risk Sciences Program FY99 Annual Report
}

Cooperative Agreement No. DE-FC02-99CH10970

Submitted To: E-mail: 2 -2393

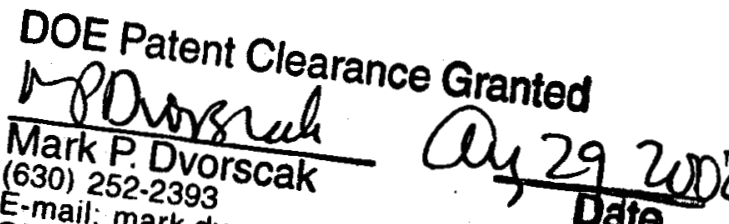

Center for Risk Excellence

OIfe of Intellectual Prop Qch.doe.gov

Chicago Operations Office

U.S. Department of Energy

Submitted By:

Dr. James L. Regens

Entergy Spatial Analysis Research Laboratory School of Public Health \& Tropical Medicine

Tulane University Medical Center

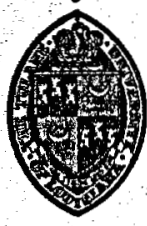

January 2000 


\section{DISCLAIMER}

This report was prepared as an account of work sponsored by an agency of the United States Government. Neither the United States Government nor any agency thereof, nor any of their employees, makes any warranty, express or implied, or assumes any legal liability or responsibility for the accuracy, completeness, or usefulness of any information, apparatus, product, or process disclosed, or represents that its use would not infringe privately owned rights. Reference herein to any specific commercial product, process, or service by trade name, trademark, manufacturer, or otherwise does not necessarily constitute or imply its endorsement, recommendation, or favoring by the United States Government or any agency thereof. The views and opinions of authors expressed herein do not necessarily state or reflect those of the United States Government or any agency thereof. 


\section{DISCLAIMER}

Portions of this document may be illegible in electronic image products. Images are produced from the best available original document. 


\section{TABLE OF CONTENTS}

\subsection{Background}

2.0 Program Focus Areas and Accomplishments

3.0 Path Forward

4.0 List of Publications and Presentations 


\section{Technology and Risk Sciences Program Progress Report}

\subsection{Background}

Developing innovative solutions for complex environmental problems requires integrating knowledge and the input from numerous scientific and technical disciplines. Data must be evaluated and communicated in a logical and understandable way to enhance its utility to a variety of audiences. The Entergy Spatial Analysis Research Laboratory (ESARL) was established in 1994 as a unit of the School of Public Health and Tropical Medicine, Tulane University Medical Center to respond to that challenge. Under the direction of Dr. James L. Regens, the Entergy Spatial Analysis Research Laboratory is committed, through its strategic planning to the establishment of internationally recognized research and educational programs. Over the last five years, ESARL has managed almost \$27 million in extramurally sponsored research funded by public and private sector clients. ESARL now maintains a diverse and growing research and development program that involves interdisciplinary teams and draws on experts from a variety of scientific and professional disciplines. The team's experience has allowed us to design an organization that fosters high-quality work performed on schedule and within budget. ESARL has developed a proven track record of conducting programs domestically and overseas.

ESARL provides a full range of state-of-the-art modeling, spatial analysis including [Geographical Information System (GIS)], and relational database management/integration capabilities to address complex environmental issues. ESARL utilizes computer hardware and software, logically structured databases, and spatial analysis expertise to create and evaluate risk scenarios, conduct predictive modeling, perform decision analysis, assess land use patterns, identify key uncertainties, delineate knowledge gaps, and evaluate technologies for environmental remediation.

To be successful in establishing and meeting realistic cleanup goals, DOE needs to develop a comprehensive understanding of the potential risks to human and ecological health at its sites as well as cost-efficient envirommental management technologies so that cleanup activities can be appropriately directed. The Center for Risk Excellence (DOE/CH-CRE) is responsible for coordinating efforts to design and evaluate tools to support risk-based, cost-efficient environmental management to achieve this end. Under funding provided by Cooperative Agreement No. FC0299CH110970, the Technology and Risk Sciences Program conducted by the Entergy Spatial Analysis Research Laboratory (ESARL) at Tulane University Medical Center is supporting the Center for Risk Excellence and DOE's mission. ESARL provides a university-based research and education program, incorporating peer-reviewed analyses, to identify, develop, evaluate, and communicate credible scientific information about significant risks and technology-based issues. The Technology and Risk Sciences Program is committed to expanding the knowledge base necessary to support the nation's environmental cleanup and policy agenda, and brings expertise and experience to bear in confronting the challenge of creating credible research, technology transfer, and educational programs that address environmental problems. TRSP's efforts help minimize risks, reduce costs, protect worker health and safety, create collaborative relationships with stakeholders and regulators, and focus technology development and deployment on cost and risk reduction. The scope of work under this cooperative agreement has built on the existing capabilities and high-value deliverables developed 
thorough the Consortium for Environmental Risk Evaluation (CERE) under a prior cooperative agreement with DOE established in May 1994.

In conducting research and training projects, ESARL draws on the expertise of highly motivated faculty and staff with strong interdisciplinary backgrounds in statistics, modeling, spatial analysis, environmental remediation, geology, forestry, economics, engineering, policy analysis, and public outreach. ESARL faculty and staff have extensive experience conducting projects dealing with environmental restoration and waste management of radionuclides and hazardous chemicals, decontamination and decommissioning (D\&D), demonstration and evaluation of environmental technologies, health and ecological risk assessment, occupational safety and health, spatial analysis (remote sensing/GIS/GPS), natural resources management, and environmental monitoring. Those projects have been conducted domestically and overseas for agencies of the U.S. Government, including the U.S. Department of Energy, National Institutes of Health, USDA Forest Service, and National Aeronautics and Space Administration, as well as commercial clients. Our experience and technical expertise allows ESARL's highly skilled faculty and staff to provide a full range of valueadded project services. The following describes our FY99 projects conducted under Cooperative Agreement No. FC02-99CH1 10970. More details about ESARL's program are available on our web site: www.esarl.tulane.edu

\subsection{Program Focus Areas and Accomplishments}

In making the transition from weapons production to environmental restoration, DOE finds it needs to develop reliable means of defining and understanding health and environmental risks and of selecting technologies so that cleanup activities can be appropriately directed. Under the Technology and Risk Sciences Program, ESARL is focusing on activities in the areas of risk assessment methodologies and technology evaluation. These activities are contributing to DOE's effort by

- Designing mechanisms for filling data and risk assessment gaps

- Developing tools to integrate the evaluation of health and ecological risks into decision making

- Enhancing risk assessment infrastructure to expedite scientifically sound risk assessment

- Validating methods for risk assessment and technology evaluation

- Developing strategies and mechanisms for meaningful stakeholder involvement in the risk assessment, technology evaluation, and risk management processes

Through the Technology and Risk Sciences Project, ESARL continues to provide DOE with products that incorporate spatial analysis techniques in the risk assessment, communication, and management processes; design and evaluate methods for evaluating innovative environmental technologies; and collaborate and access technical information on risk assessment methodologies, inchuding multimedia modeling and environmental technologies in Russia and the Ukraine. In addition, as a university-based 
research and education program, ESARL is contributing to training and developing the skills of the next generation of scientists and environmental professionals.

Maintaining the technical and scientific quality of TRSP's work is essential for the Technology and Risk Science Program to help meet DOE's needs. All of the substantive efforts conducted under this cooperative agreement have been subjected to the review and guidance of an external review panel specifically selected for this program. Such external review is integral to designing, conducting, and providing an independent appraisal that will promote immediate scientific and public credibility and advance the ongoing national dialogue over environmental management at the weapons complex. It is a critical element of the QA/QC approach and provides a continuing review of the work product by peers from all of the relevant disciplines. Members of the independent science advisory committee have expertise in risk assessment, occupational health and safety, risk communication, environmental engineering, modeling, and environmental management.

\section{TRSP SCIENCE ADVISORY COMMITTEE}

Evgeny N. Avorin, Ph.D.

Former Advisor to the Russian President on Nuclear Physics and Scientific Director, Russian Federal Nuclear Center Institute of Nuclear Physics

Colonel Patrick Fink, P.E. Director, Pollution Prevention, US Air Force Center for Environmental Excellence

Timothy A. Hall, Ph.D.

President, ManTech Environmental Corporation and Man Tech Environmental Technology, Inc.

Lawrence C. Mohr, M.D., FACP, FCCP Professor of Medicine and Director, Environmental Hazards Assessment Program, Medical University of South Carolina
Oles A. Pyatak, M.D., Ph.D.

Deputy Director General, Research Center for Radiation Medicine, Academy of

Medical Sciences of Ukraine

Glenn Paulson, Ph.D.

President of Paulson and Cooper, Inc. and Member of the DOE Environmental

Management Advisory Board

Lynne M. Preslo, P.G.

Senior Vice President, Earth Tech

Myron F. Uman

Associate Executive Officer, National

Research Council

Chris G. Whipple, Ph.D.

Vice President, ICF Consulting

\subsection{Risk Assessment Methodologies}

The development and application of methods for health and ecological risk assessment represents one of the key ways to link an understanding of the dynamics of pollutant transport and fate within and across environmental media to the effects on human health or ecological receptors as the basis for risk management. 


\subsubsection{Risk-based Science and Technology Integration Project}

The reduction of near-term risks and long-term management of residual risks associated with contaminated sites within the nuclear weapons complex is a major challenge facing the U.S. Department of Energy's Environmental Management Program. Numerous individual projects ranging from decommissioning nuclear reactors and other facilities to management of waste storage and disposal areas (i.e., underground tanks and past burial or discharge areas) and contaminants that have moved into and through the soil to groundwater and surface water have been proposed. Providing the analytical basis necessary to generate reliable estimates of risk as well as evaluate the effectiveness of remediation alternatives to support credible decision-making is a key driver for DOE's Environmental Management Science and Technology (S\&T) program. Tulane University Medical Center, in collaboration with the Medical University of South Carolina and Argonne National Laboratory, participated in the Hanford Groundwater/Vadose Zone Integration Project and developed an integrated conceptual approach for identifying risk-based S\&T requirements to support site decisions and assess long-term stewardship strategies.

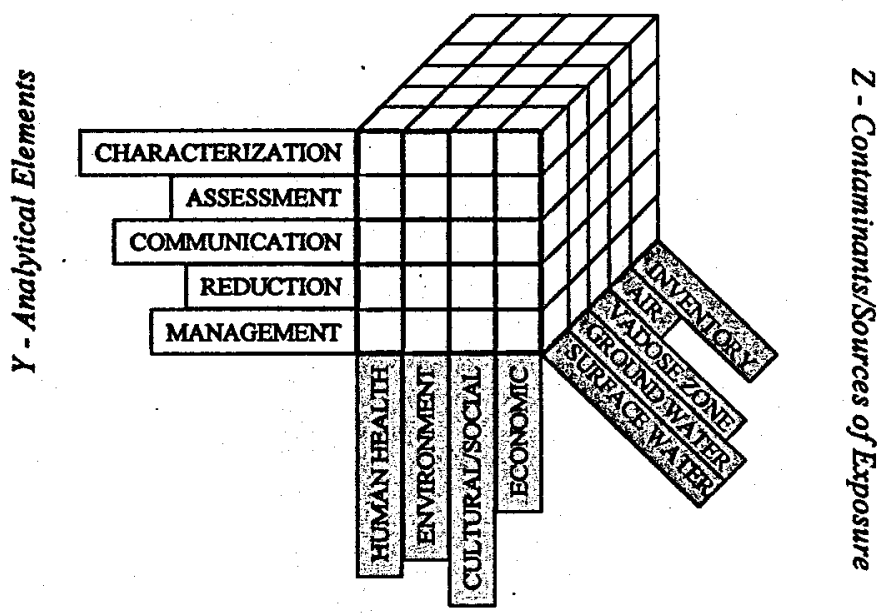

$X$-Potential Receptors/Impacted Resources

Risk-Based Science and Technology Matrix

The approach developed a three-dimensional matrix as a device for identifying risk-based S\&T information requirements and research priorities. The $\mathrm{x}$-axis of the matrix is comprised of potential receptors and impacted resources. The y-axis is comprised of analytical elements that shape riskbased S\&T needs. The z-axis of the matrix is comprised of the major contaminants and sources of exposure that define the hazards and potential for risk. Information obtained through a review of available data and documents combined with expert judgment was used to define the content of the cells in the matrix. Completion of the matrix produced an integrated risk-based S\&T agenda reflecting key information gaps or uncertainties about potential risks to human health, the environment, cultural/social resources, and economic resources from contaminants at DOE sites. The requirement for developing tools to effectively communicate risks (y-axis) to human health ( $x$-axis) from contamination impacting the vadose zone (z-axis) provides an example of the results of using this 
approach to develop a risk-based S\&T agenda.

This approach can be used to set a risk-based science and technology agenda for remediation and long-term stewardship. It also can help define uncertainties in existing knowledge. Identifying risk science and technology activities that address significant data gaps and uncertainties and then reducing those gaps and uncertainties by focusing S\&T resources is central to producing reliable assessments of risk that support credible decision making. This approach was used to identify risk elements of the Hanford Groundwater/Vadose Zone Integration Plan's S\&T Road Map. Because many significant risk issues cut across the nuclear weapons complex, the analysis has complex-wide utility for DOE's environmental management program.

Accomplishments

- Regens, J.L., P.L. Wilkey, R.E. Zimmerman, D.G. Hodges, L.C. Mohr, and G. Fleming, "A Risk-Based Approach for Setting an Environmental Science and Technology Agenda for the U.S. Department of Energy Nuclear Weapons," Environmental Science and Pollution Research (forthcoming).

- J.L. Regens, L.C. Mohr, P.L. Wilkey, E. Zimmermen, D.G. Hodges, G. Fleming, An Integrated Conceptual Approach to Setting a Risk-based Science and Technology Agenda, Tulane University Medical Center, Entergy Spatial Analysis Research Laboratory, New Orleans, LA, Report prepared for the U.S. Department of Energy Center for Risk Excellence, May 1999.

- P.L. Wilkey, J.L. Regens, D.G. Hodges, E. Zimmerman, G. Fleming, L.C. Mohr, Risk Science and Technology Element of the Applied Science and Technology Plan for the Hanford Groundwater/Vadose Zone Integration Project, Tulane University Medical Center, Entergy Spatial Analysis Research Laboratory, New Orleans, LA, Report prepared for the U.S. Department of Energy Center for Risk Excellence, February 1999.

- P.L. Wilkey, J.L. Regens, D.G. Hodges, E. Zimmerman, G. Fleming, L.C. Mohr, Risk Science and Technology Technical Report for the Hanford GW/VZ Integration Project, Tulane University Medical Center, Entergy Spatial Analysis Research Laboratory, New Orleans, LA , Report prepared for the U.S. Department of Energy Center for Risk Excellence, January 1999.

- J.L. Regens, D.G. Hodges, P.L.Wilkey, R.E. Zimmerman, L.C. Mohr, G. Flemming, “A Risk-Based Approach for Evaluating Science and Technology Priorities for Environmental Management at the U.S. Department of Energy Nuclear Weapons Complex," Proceedings of the $2^{\text {nd }}$ ISTC/SAC Seminar, "Large Scale Area Remediation," Snezhinsk, Russia, 1999.

- Dr. Regens presented results of work supporting the Hanford Groundwater/Vadose Zone Project at the "International Symposium on Society and Resource Management" in Brisbane, Australia in July 1999. He was also invited to meet with officials of Australia's 
Department of Environment and Heritage to discuss U.S. and Australian strategies for integrated resource management and long-term stewardship.

\subsubsection{Risk Analysis and Visualization}

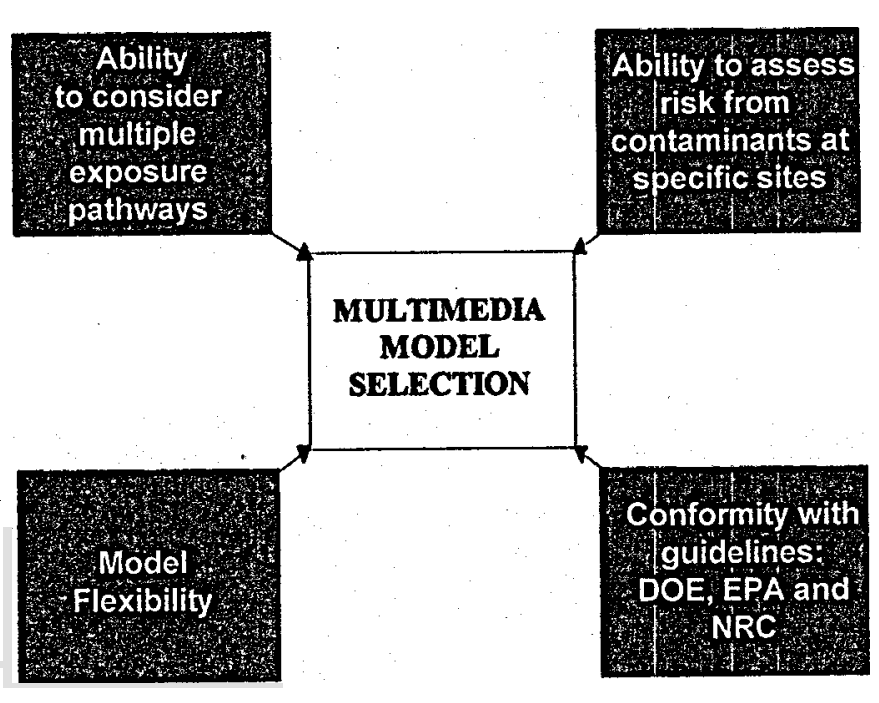

Criteria for Multimedia Model Selection
Identifying the most significant risks to the public, workers, and the environment as DOE remediates its sites is a complex challenge. Computer-based multimedia models are key analytical tools for assessing potential present day as well as future human and ecological exposure to environmental contaminants. Multimedia models organize and summarize available knowledge about environmental settings, contaminant sources, pollutant transport through multiple media, and exposure pathways to estimate relative risk. These models can be used to (1) predict the movement of potentially toxic materials; (2) determine the exposure an individual might receive in a lifetime; and (3) estimate the health risk from that exposure. Our research team compared the performance and similarity of results of three major multimedia models-MEPAS, RESRAD, and MMSOILS-in two case studies using actual release site data from Oak Ridge National Laboratory and the Rocky Flats Environmental Technology Site.

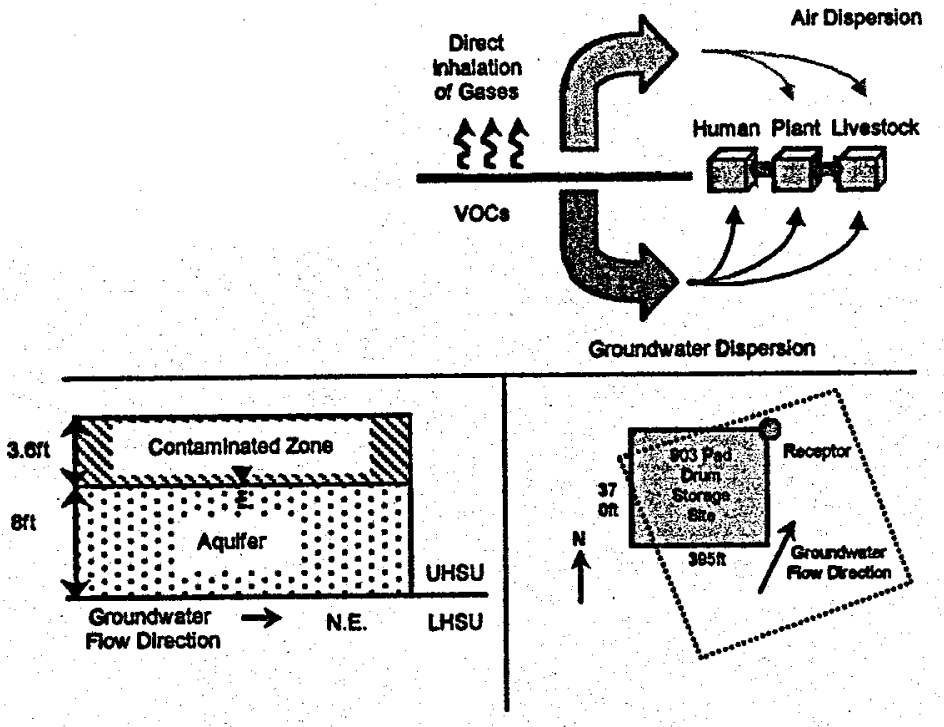

Rocky Flats, CO Conceptual Site Model: VOCs in Groundwater and Air 
Building on the results of our multimedia model comparison effort, the Technology and Risk Sciences Program is integrating geographical information systems and multimedia modeling (using Access and Visual Basic programs) to develop an ArcView site characterization interface that allows the user to interactively visualize/characterize a waste site and view the results of a RESRAD nu in ArcView. Earlier versions of multimedia models have traditionally lacked a visual component, a link between a Geographic Information Systems (GIS) and risk analysis. Integrating multimedia modeling into a GIS environment will allow for 1 ) incorporating spatial analysis techniques into the risk assessment, communication, and management process and 2) developing and applying methods that utilize GIS and other spatial analysis techniques to identify the distribution of contaminants and receptors and assess multipathway exposure patterns on a spatial and temporal basis. The prototype GIS interface will be used with RESRAD version 5.82 , a multimedia model developed by Argonne National Laboratory. Through the proposed interface, the user can input parameters (e.g., contaminants, soil types); visualize spatially-related site characteristics (e.g., contaminant plumes); perform RESRAD analyses; and display results based on contaminants of concern, transport and exposure pathways, medium, and time.

\section{Accomplishments}

- Designed PC-based demonstration version of preliminary graphics and database management modules

- J.L. Regens, K.R. Obenshain, C.C. Travis, M. Clauberg. "Applying Multimedia Modeling to Karst Systems: Comparing MEPAS, MMSOILS, and RESRAD," Environmental Geosciences 1999; 6(3), pp. 115-122.

- C.C. Travis, K.R. Obenshain, J.L. Regens, C.G. Whipple. "Limitations of Multimedia

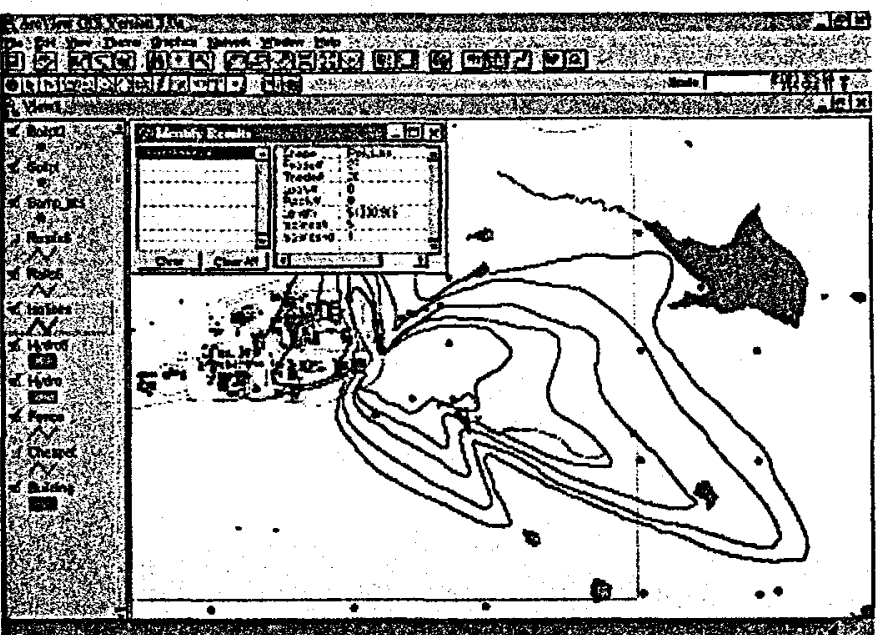

Risi. Analysis and Visualization

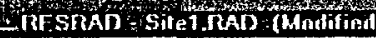

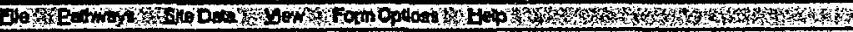

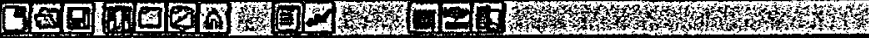

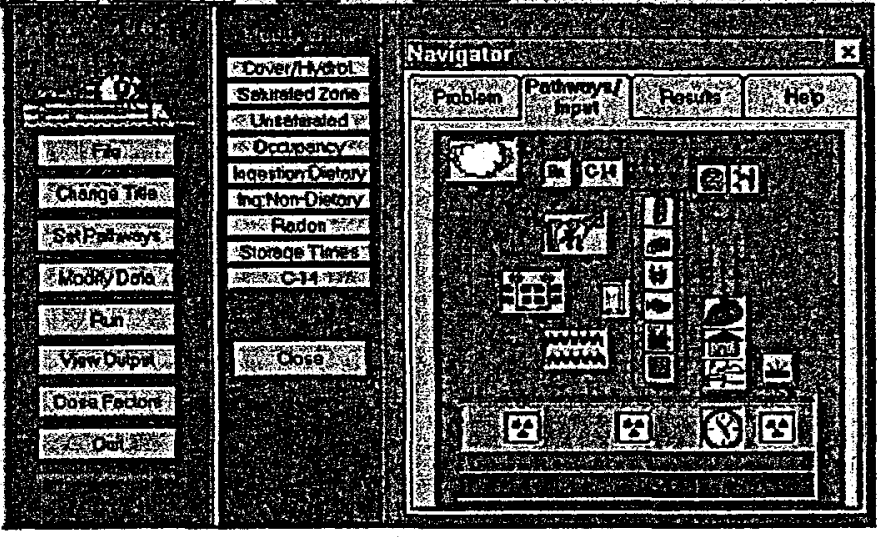

Interface windows (Arcview 3.0a, Microsoft Access 97, RESRAD version 5.82) 
Models for Use in Environmental Decision Making," Environmental Monitoring and Assessment (forthcoming).

- J.L. Regens, C.C. Travis, K.R. Obenshain, C.G. Whipple, J.T. Gunter, V. Miller, et al. Multimedia Modeling and Risk Assessment. The Medical University of South Carolina Press, 1999.

- M. Clauberg and J.L. Regens, "Comparison of Multi-Media Model Results of the Consortium for Environmental Risk Evaluation," in A. Troge, ed., Proceedings of the Concerted Action for Contaminated Sites in the European Union International Workshop on Risk Assessment Models and Risk Management for Contaminated Sites (Berlin, Germany: Federal Ministry for the Environment, Nature Conservation and Nuclear Safety, 1998), pp.121-131.

- Regens James L., Karen R. Obenshain, Curtis Travis, James T. Gunter, Vincent Miller. 1999. Multimedia modeling of environmental restoration risks at Rocky Flats. Presented at: Waste Management 99. Tucson, Arizonia. February 28 - March 4, 1999.

- M. Clauberg and J.L. Regens, "Comparison of Multi-Media Model Results of the Consortium for Environmental Risk Evaluation," presented at the European Commission International Workshop on Risk Assessment Models and Risk Management for Contaminated Sites, Berlin, Germany, April 23-24, 1998.

\subsection{Technology Evaluation}

Environmental managers confront the challenge of making decisions to select and deploy remediation technologies to address a variety of problems. These choices are increasingly more complex because a greater variety of contamination problems are being defined and innovative technologies are becoming available as potential alternatives to existing technologies. Managers are further challenged because they are compelled to integrate information about relative risk into their considerations of remedial actions and also are required to balance information about technology performance and risk with fixed or limited budgetary resources and regulatory constraints. In addition, information about the concerns of stakeholders, as well as their meaningful involvement in the larger decision process, influences the ultimate technology selection and deployment decision. Environmental managers need better tools to help them assemble and synthesize information to design and implement risk-based, cost-effective environmental management decisions about remediation priorities and alternatives. Our research team has conducted a series of projects to develop decision support tools that help meet this important DOE need.

\subsubsection{Project Screening Approach for Office of Science and Technology Peer Review}

Evaluating technologies in terms of their capabilities for meeting remediation end points and longterm stewardship options is a major requirement of the U.S. Department of Energy's Environmental Management Program. The ability to conduct timely, independent peer review of Office of Science and Technology (OST) projects is a key element in meeting this requirement. However because of 
conditions of constrained funding and time, there is a backlog of OST projects which never have been subjected to an external, independent peer review. Under the direction of the Director of the Center for Risk Excellence, who is the Peer Review Coordinator, a team consisting of personnel from the Center for Risk Excellence, ESARL, and Argonne National Laboratory was formed to develop a formal, pre-screening process that would identify OST projects which would benefit most from such a review prior to implementing an extensive peer review by the American Society of Mechanical Engineers.

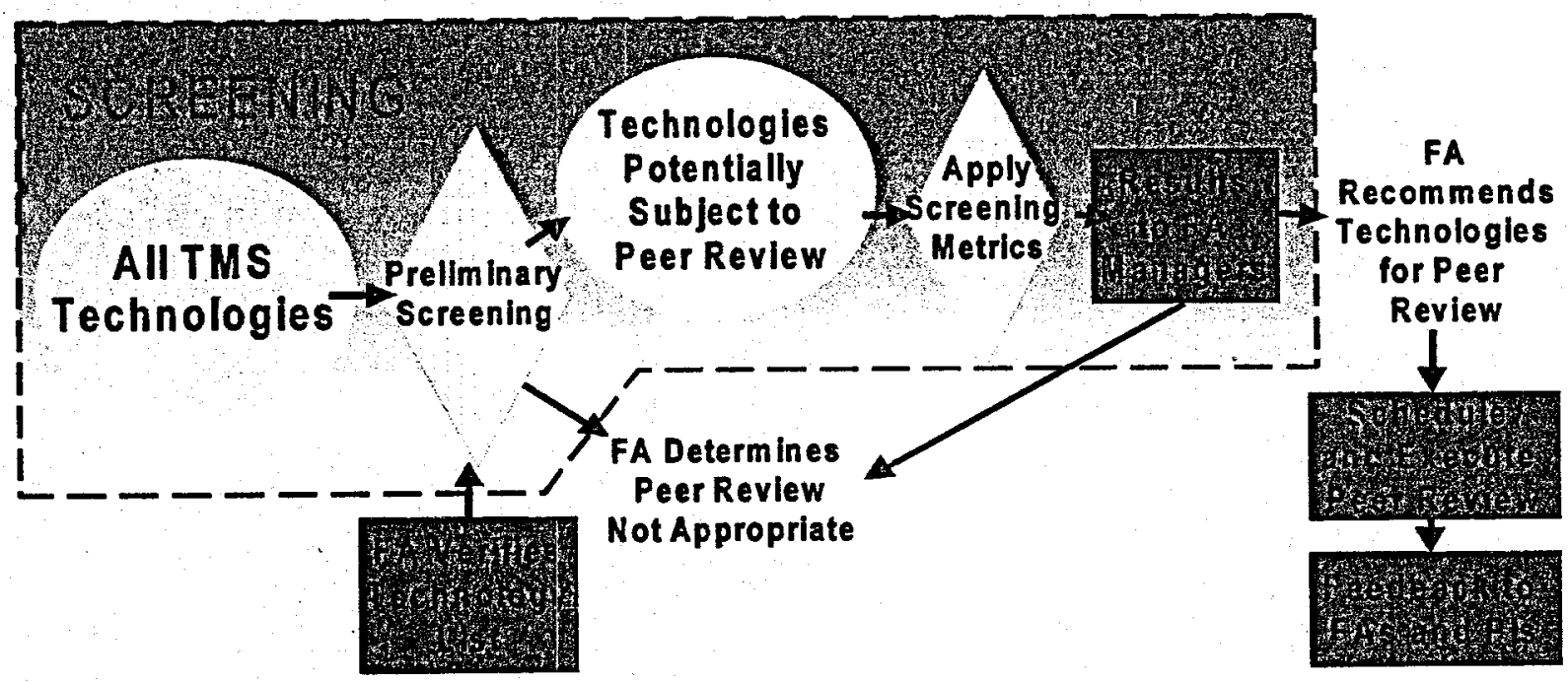

\section{Project Screening Relationship to Peer Review}

The project screening approach developed provides an integrated decision support tool for assembling, synthesizing, and communicating information needed to support the allocation of limited peer review assets. It is a defensible, transparent, reproducible system designed to produce the greatest benefit from the application of limited peer review resources for OST projects. The project screening approach provides a mechanism for screening individual projects based on the quantitative criteria of total DOE investment in FY99 dollars, relevancy to DOE needs, and availability to meet schedule requirements. The three criteria are defined as follows:

- Investment-funding provided by DOE EM from the project inception through FY99 inclusive, allowing for the capture of possible gap funding and/or cost sharing by OST and other EM offices

- Relevancy-the degree to which a technology responds to one or more priority needs identified by a focus area

- Availability - whether the technology is scheduled for implementation prior to or when required as identified in the Needs Management System 

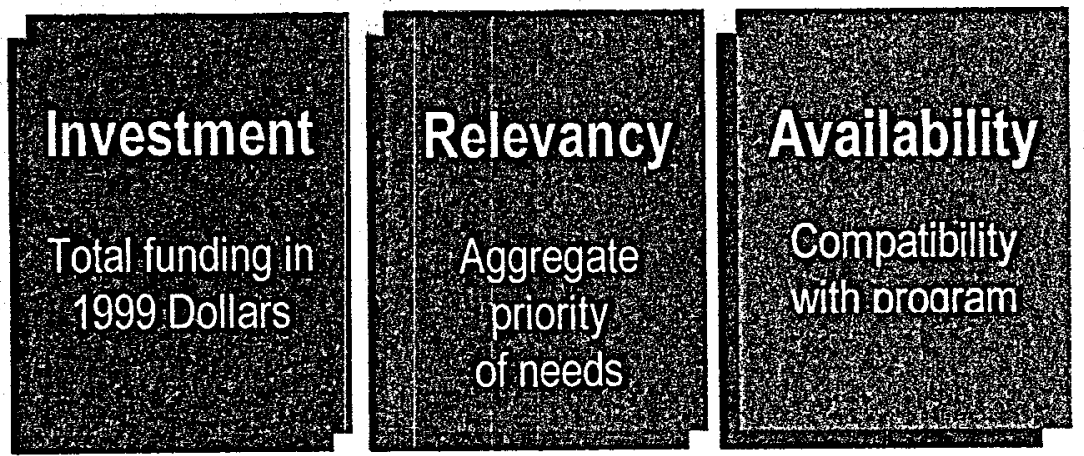

Project Screening Approach Criteria

Measures for each criterion were computed through associated indicators (DOE funding, relevance index, and schedule status, respectively).

The project screening approach provides a consistent appraisal of OST technology projects. The output generated by the project screening approach supports FA managers' identification of new or continuing active projects that maximize benefits from the application of limited peer review resources. The screening approach integrates information about project status into the overall peer review process while maintaining existing responsibilities.

The initial application of the project screening approach concentrated on active technology projects managed by the Focus Areas. The output from the project screening approach will be used to support FA managers' recommendations of projects for peer review in the FY 2000 peer review cycle.

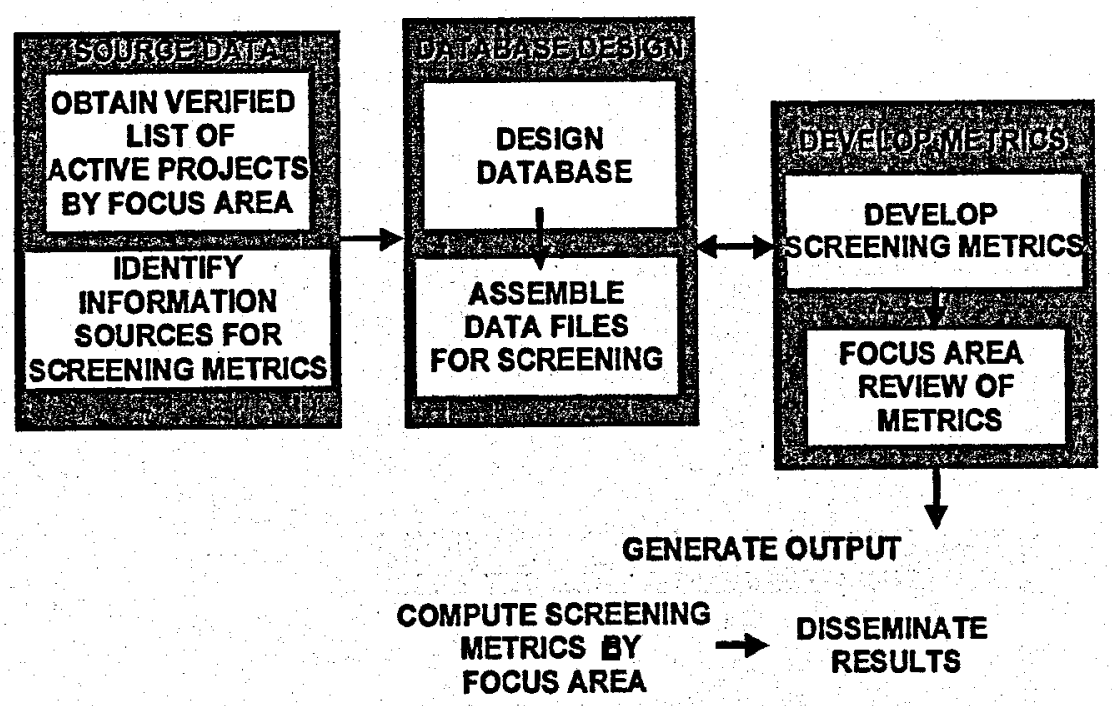

Process Flowchart for the Project Screening Approach 


\section{Accomplishments}

- P.L. Wilkey, J.L. Regens, M.C. Dionisio, E. Zimmerman, Project Screening Approach for the Office of Science and Technology Peer Review Program, DOE/CH/CRE-3-1999, Center for Risk Excellence, September 1999.

- J.L. Regens et al, "A Project Screening Approach to Prioritizing Environmental Management Technology Review," to be presented at Waste Management 00, Tucson, Arizona, February 27-March 2, 2000.

\subsubsection{U.S.-Russian Initiatives for Environmental Remediation}

The Russian Federation confronts significant scientific and technical challenges in terms of developing cost-efficient, risk-based strategies to utilize environmental technologies for cleanup and long-term stewardship at the Russian Federation nuclear weapons complex. The end of the Cold War and the ensuing collapse of the Soviet Union has created unique opportunities for scientists and engineers in the former Soviet nuclear weapons complex to collaborate in developing, evaluating, and commercializing promising environmental technologies and risk assessment methodologies. ESARL, in collaboration with Argonne National Laboratory, is participating in U.S.-Russian projects which will foster such opportunities for mutually beneficial collaboration. These projects support the U.S. Government's cooperative threat reduction program. Support for Russian participation is provided by the International Science and Technology Center (ISTC), including Project \#787 which focuses on designing and developing new polyfunctional compounds for remediation of radionuclide, heavy metal, and organic contamination.

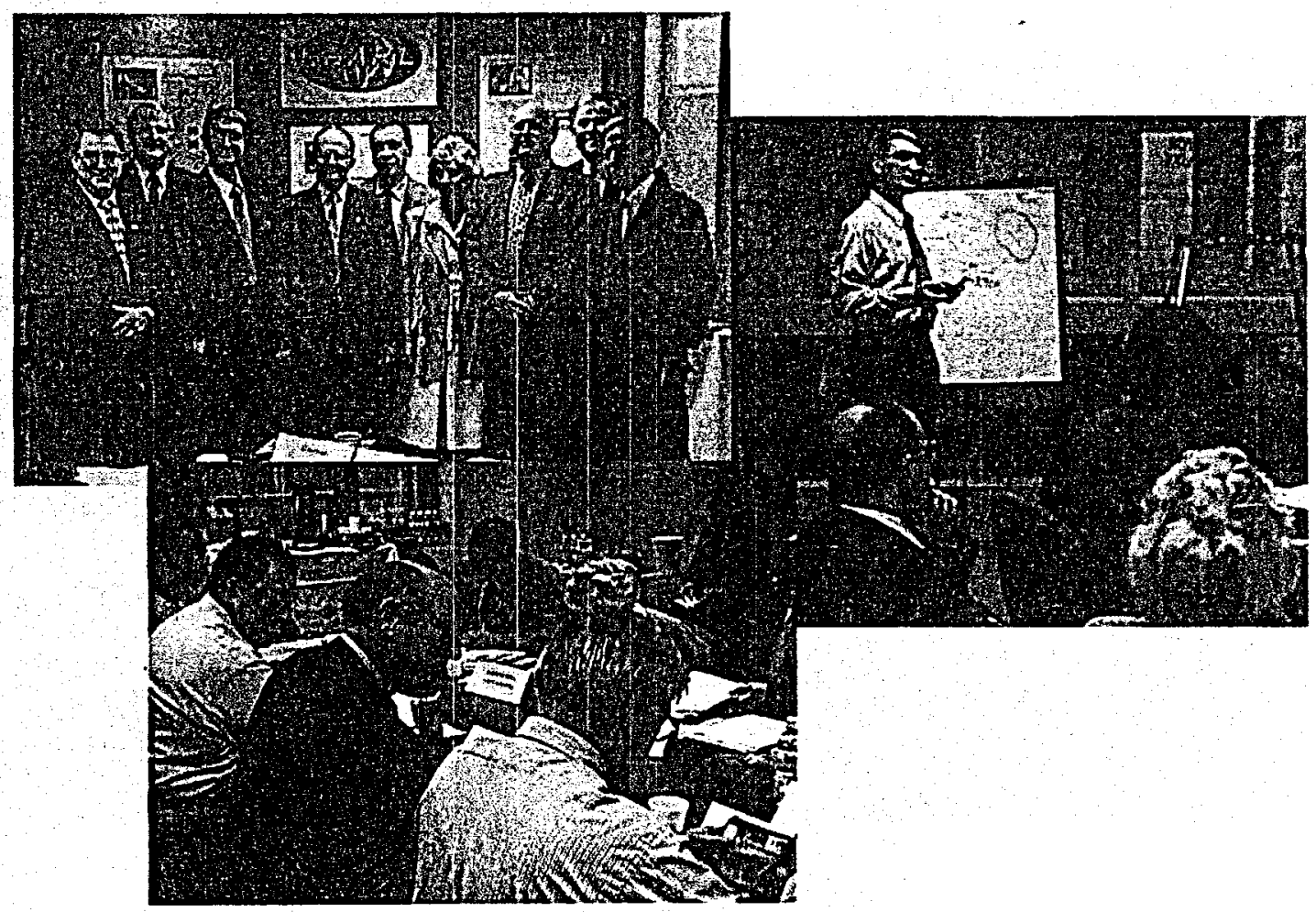

December 1998 Meeting at Tulane University Medical Center 
ESARL has established relationships and enjoys ongoing cooperation with a number of key Russian government institutions, including the Ministry of Russian Federation for Atomic Energy (Minatom), the Kurchatov Institute, the Russian Federal Nuclear Research Center (Chelyabinsk-70), Nuklide, and the Medical Radiological Scientific Center of the Russian Academy of Medical Sciences. For example, we are collaborating with the Russian Federal Nuclear Center on projects related to innovative technologies for disposing of radioactive waste and risk assessment of sites that compose the Russian nuclear weapons complex. We have established a basis for scientific and technical cooperation with the Russian Academy of Sciences (Far East Branch) which is involved in the development and deployment of innovative technology for disposing of liquid radioactive waste generated by the Russian Navy's Pacific Fleet. Additionally, we established a working relationship with the Ukrainian Center of Radiation Medicine in Kiev. Dr. Regens also is a scientific collaborator on an International Scientific and Technical Center project (Project \#KR-072) focusing on the identification of spatial distribution of radioactive and heavy metals tailing storage sites in Northern Kyrgyzstan. Project objectives include measuring the total gamma radioactivity and the content of heavy metals.

Activities for this initiative include a series of small group, interactive workshops coupled with scientific exchanges to (1) identify and access Russian innovative technologies, (2) review the stateof-the-art for risk assessment, and (3) improve understanding of the technical and scientific infrastructure requirements to support long-term stewardship. Workshop locations alternate between the U.S. and Russia. Workshops have been held at Tulane University Medical Center in New Orleans, LA, USA; Argonne National Laboratory in Chicago, IL, USA; and in Snezhinsk, Russia.

\section{Accomplishments}

- J.L. Regens, D.G. Hodges, P.L.Wilkey, R.E. Zimmerman, L.C. Mohr, G. Flemming, “A Risk-Based Approach for Evaluating Science and Technology Priorities for Environmental Management at the U.S. Department of Energy Nuclear Weapons Complex," presented at the $2^{\text {nd }}$ ISTC/SAC Seminar on Large Scale Area Remediation sponsored by the Russian Federal Nuclear Center, Institute in Technical Physics (RFNC-VNIITF), Snezhinsk, Russia, June 1999.

- Zimmerman J.L. Regens, P.L. Wilkey, "Muttiparametric Tool for Evaluation of the Development and Deployment of Innovative Remediation Technologies," presented at the $2^{\text {nd }}$ ISTC/SAC Seminar on Large Scale Area Remediation sponsored by the Russian Federal Nuclear Center, Institute in Technical Physics (RFNC-VNIITF), Snezhinsk, Russia, June 1999.

- Researchers from Tulane University Medical Center; Argonne National Laboratory; IVAUral State Economic University, and the Russian Nuclear Research Center, Institute of Technical Physics met in Chicago in February 1999 and November 1999. The joint collaborative effort produced an invention disclosure for a wide-spectrum chemical analyzer that can detect, measure, and differentiate metals in aqueous phase and volatile organics in gaseous phase. 
- ESARL hosted a two-day workshop for senior Russian scientists, led by Academician Evgeny Avrorin, Scientific Director of the Russian Federal Nuclear Center-Zababakhin Institute of Technical Physics (VNIITF), and representatives of Argonne National Laboratory and the U.S. Department of Energy in December 1998.

- Dr. Regens has presented Guest Seminars on strategies for radioactive waste management and risk assessment at a number of Russian institutes, including the RCC Kurchatov Institute, the All-Russian Research Institute of Chemical Technology, and the Zelinsky Institute of the Russian Academy of Sciences.

- Dr. Regens was invited to participate in the 3rd International Conference on Ecology and Development of the Russian Northwest Region, sponsored by the International Academy of Ecology, Man and Nature Protection Services; RF Ministry of Atomic Energy, RF Ministry for Emergency Situations; and the Russian Academy of Sciences.

\subsubsection{Tools for Evaluating Environmental Technology}

ESARL led a university-national laboratoryconsulting firm team in developing a Technology Evaluation Framework to identify and compare information about conventional and innovative technologies for environmental remediation. The Technology Evaluation Framework provides a standardized process that allows environmental managers to integrate the diverse factors that influence the selection and deployment of environmental technologies. Eight measurable criteria with specific indicators are employed to assess the capability of a technology or suite of technologies to address environmental restoration problems on a site-specific basis. The Technology Evaluation Framework does not employ a series of preassigned

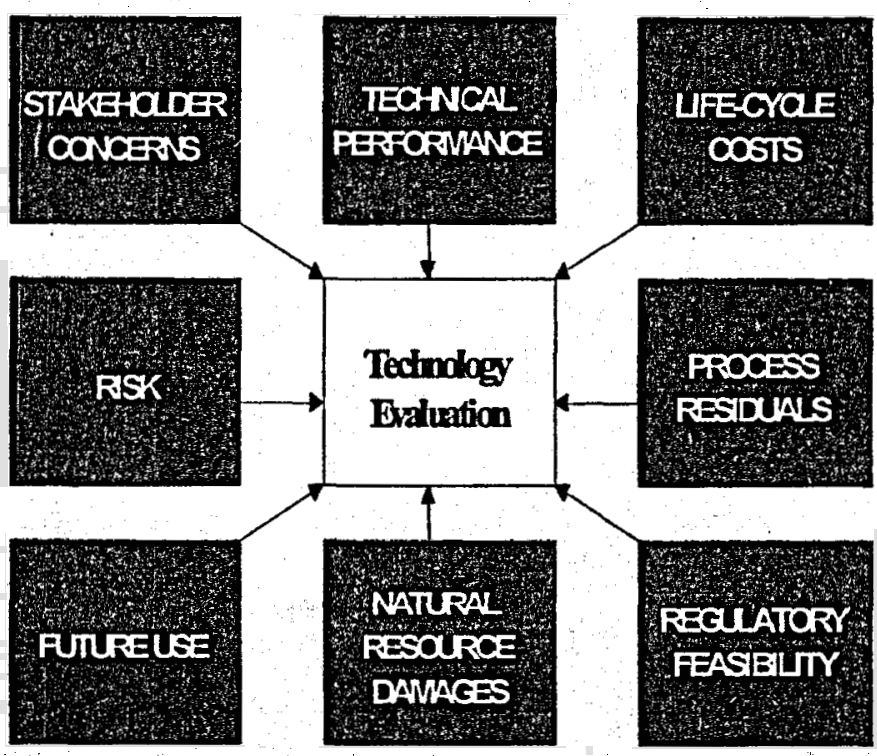

Technology Evaluation Framework Criteria weights for each of the criteria. Instead, it represents a flexible approach, allowing trade-offs among the eight criteria on the basis of site-specific needs, such as temporal or physical constraints, schedule demands, and funding profiles. Environmental managers can use the Technology Evaluation Framework to assess the effectiveness of individual technologies or remedial alternatives, which may consist of various technologies or suites of technologies, in meeting site-specific goals. The Technology Evaluation Framework enables environmental managers to identify and systematically compare information about the ability of innovative and conventional technologies to meet remediation goals for their site. The completed Framework provides the environmental manager with a documented, reproducible evaluation, which can be updated as new information becomes available. 


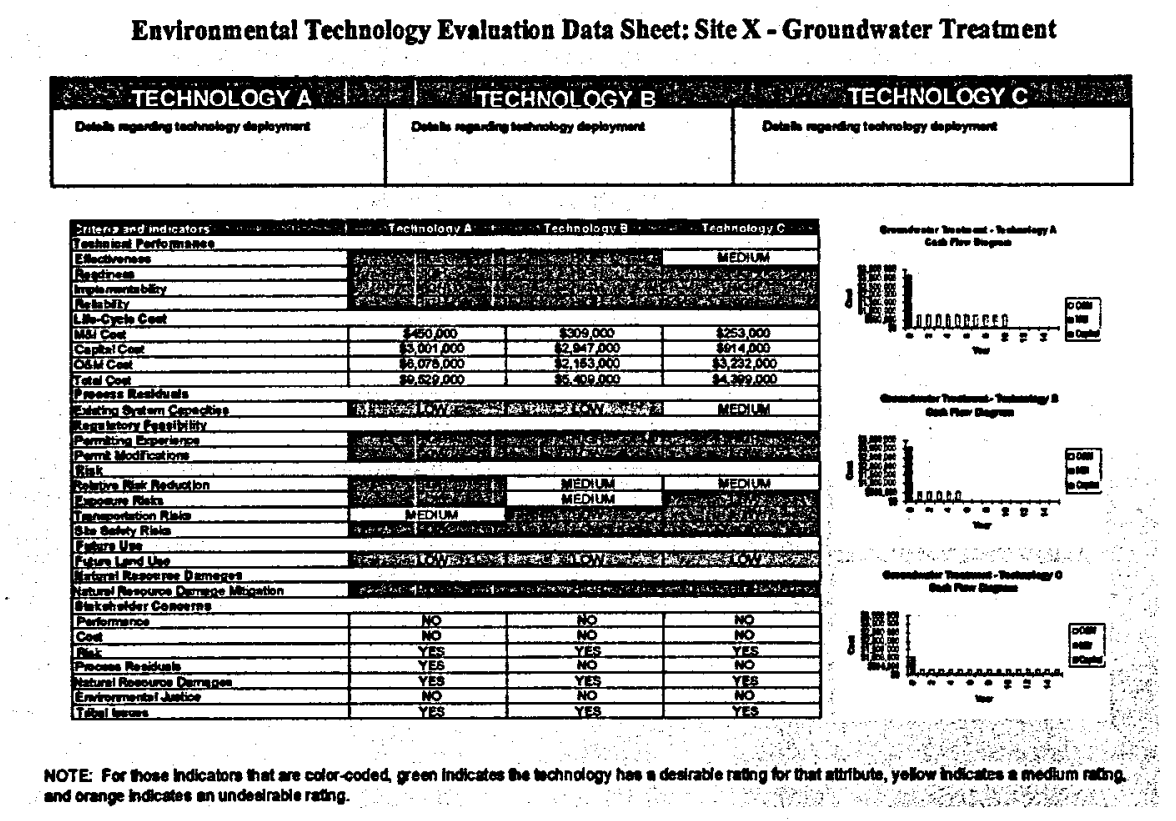

Example of Environmental Technology Evaluation Data Sheet

The pilot application of the Framework utilized data from three DOE and one DoD installation to evaluate technologies for containment and treatment of soil and groundwater contaminated by TCE. Although the Framework was developed for DOE, it has far-ranging potential for application as a management tool in the private sector and for other federal facilities.

In addition, ESARL co-sponsored the "Development and Application of Environmental Technologies for Federal Facilities Cleanup: Issues and Opportunities for Indian Tribes" workshop organized by the International Institutes for Indigenous Resource Management. Additional co-sponsors included the Council of Energy Resource Tribes; the U.S. Environmental Protection Agency, Office of Federal Facilities Restoration and Reuse and Office of Solid Waste, Emergency Response; the U.S. Department of Energy, Center for Risk Excellence; and the National Indian Business Association. The facilitated workshop brought together Tribal Council members, attorneys, natural and cultural resource specialists and environmental protection professionals to 1) help tribal professional staff and decision makers gain and understanding of characterization, remediation, and monitoring technologies; 2) provide tribal professional staff and decision makers with the tools they need to knowingly and intelligently participate in technology selection decisions; 3) help federal facility managers, regulators, and technology developers appreciate the wide range of tribal interests that can be affected by technology development and deployment decisions; 4) help federal facility managers and regulators understand the legal drivers that require consideration of tribal interests in technology development and deployment decisions; and 5) spur tribal-federal-private partnerships around the planning, research, development, testing, and fabrication of environmental technologies. At the workshop, interest was expressed in using the Technology Evaluation Framework, or a modification of it, for assisting Tribal governments in participating in technology development and deployment decisions. 


\section{Accomplishments}

- James L. Regens, Patrick L. Wilkey, Eugene A. Hughes, Donald G. Hodges, Anthony Q. Armstrong, Linda Kelley, Eric Zimmerman, and Al J. Unione. "An Integrated Framework for Environmental Technology Evaluation” Prabhu Dayal, ed., Innovative Remediation Technologies (forthcoming).

- Regens, J.L., R.E. Zimmerman, P.L. Wilkey, D.G. Hodges, A.Q. Armstrong, and L. Kelley. "Evaluating Environmental Technology for Meeting Remediation End Points and Long-Term Stewardship Options," Environmental Science and Pollution Research (forthcoming).

- J.L. Regens, "Tools for Evaluating Environmental Management Technologies" presented at the Development and Application of Environmental Technologies for Federal Facilities Cleanup: Issues and Opportunities for Indian Tribes Workshop sponsored by the International Institutes for Indigenous Resource Management et al, Denver, December 1999.

- Zimmerman, R.E., J.L. Regens, P.L. Wilkey, "Multiparametric Tool for Evaluation of the Development and Deployment of Innovative Remediation Technologies," Proceedings of the 2nd ISTC/SAC Seminar "Large Scale Area Remediation," Snezhinsk, Russia,1999, pp. 5.1-5.10.

- J.L. Regens, D.G. Hodges, L.Kelley, T.A. Sands. "Site Remediation Technologies," The Military Engineer 1999; 91(601), pp. 57-58.

- J.L. Regens, D.G. Hodges, P.L. Wilkey, L. Kelley, E. Zimmerman, A.Q. Armstrong, L. Kelley, et al. "Integrated Framework for Evaluating Subsurface Contamination Remediation Technologies," Environmental Geosciences 1999; 6(2), pp. 82-87.

- Regens, J.L., D.G. Hodges, P.L. Wilkey, E. Zimmerman, A.Q. Armstrong, L. Kelley, T.A. Hall, and E.A. Hughes, "Screening Technologies for Soil and Groundwater Remediation," Soil \& Groundwater Cleanup 1999; pp. 24-27.

- J.L. Regens, D.G. Hodges, P.L. Wikey, L. Kelley, A.Q. Armstrong, R.E. Zimmerman, et al An Integrated Framework for Environmental Technology Evaluation. The Medical University of South Carolina Press, 1999.

- J.L. Regens, D.G. Hodges, P. Wilkey, L. Kelley, A. Armstrong, E. Zimmerman, T.A. Hall, and E.A. Hughes, "Integrated Framework for Assessment of Site Remediation Options," presented at the Waste Management 98 Symposium, Tucson, March 1-5, 1998. 


\subsection{Training and Education in Environmental Health Sciences}

Research universities are uniquely positioned to play a significant role in building the fundamental knowledge base necessary to support the nation's environmental clean up and policy agenda by training the next generation of scientists and environmental professionals. Through advanced education and research in such fields as health sciences, ecology, and environmental engineering, they potentially represent a major source of intellectual talent for meeting the challenge of making risk-based decisions grounded in credible, technical information.

Transforming that potential into a reality will require society to sustain active investment in supporting research and educational activities. That

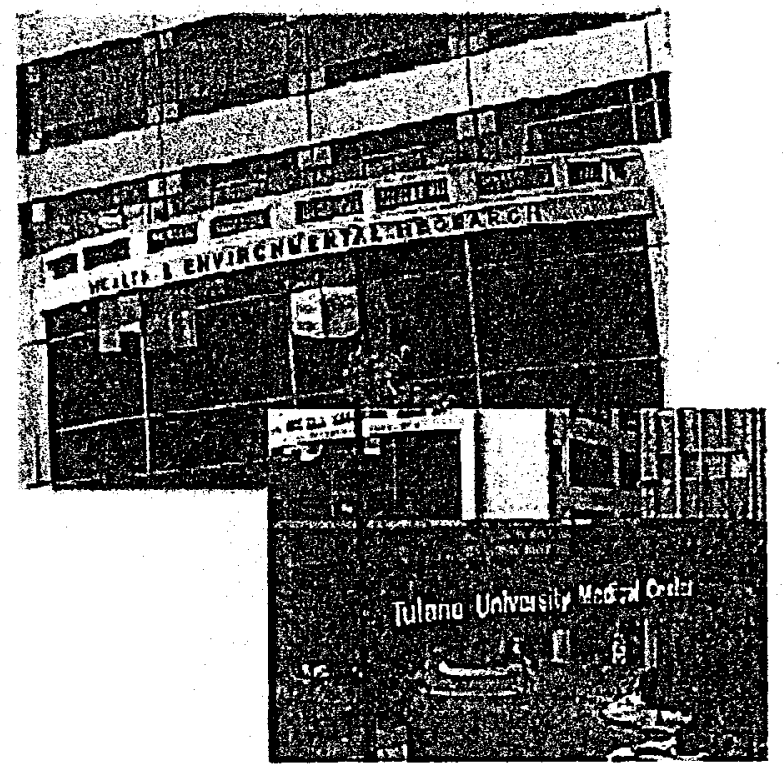
investment in fundamental research and training is important for several reasons. First, developing a credible scientific and technical base for remedial actions and long-term stewardship rests on improving existing knowledge and understanding. Second, DOE and its stakeholders are likely to enhance their ability to set priorities and make tradeoffs among alternatives as DOE becomes better informed about the public's concern and stakeholders become more capable of making informed judgements on probable risks. Third, the workforce of trained professionals necessary to design and implement programs will come from the current generation of students and junior faculty. Providing opportunities for junior faculty and graduate students to apply their academic training to real world projects is critical to sustaining and enhancing the knowledge base and pool of professionals that will be needed to develop and implement effective solutions to complex and often contentious problems.

Through its cooperative agreements with DOE, ESARL, as a unit in the School of Public Health and Tropical Medicine at Tulane University Medical School, has participated in training professionals to meet those needs. Using an interdisciplinary approach to environmental health sciences, ESARL provides opportunities to develop an in-depth understanding of the principles and application of analytical skills for risk assessment and environmental remediation. The Technology and Risk Science Program has used Tulane University as the integrating entity for a nation-wide initiative, bringing together nationally recognized experts from universities, national laboratories, and the private sector to address focused tasks. Tulane University has formed partnerships to focus the best technical minds on DOE's environmental problems, while utilizing high levels of quality control and review so as to ensure scientifically credible conclusions. Through these partnerships, ESARL has provided opportunities for graduate students and junior faculty to develop collaborative and mentoring relationships with professionals nation-wide, and even internationally. 
ESARL has supported 3 postdoctoral fellows and 31 doctoral and master's candidates. In addition, ESARL has published numerous books, peer-reviewed articles; and presented research results at national and international professional conferences. (See Section 4.0.)

\subsection{Path Forward}

Our activities in FY99 demonstrate a strong and continuing record of research

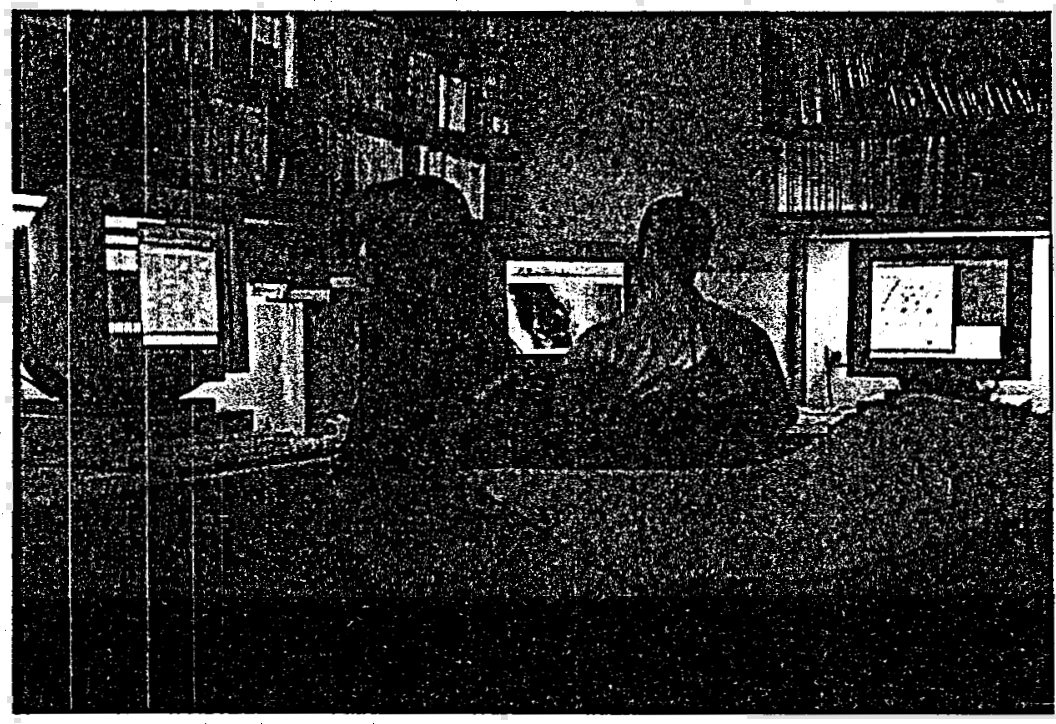
productivity. ESARL has been successful in maintaining a high level of publication in peer review journals, collaboration with national laboratories and other academic institutions, and mentoring of graduate students and post-doctoral fellows. The partnership with DOE's Center for Risk Excellence has been instrumental in sustaining our success.

The primary goal in FY00 is to enhance our contributions to developing and applying credible scientific approaches with meaningful stakeholder involvement, to assess technology performance, evaluate risks, estimate life cycle costs, and analyze public concerns linked to the cleanup of the DOE nuclear weapons complex. ESARL envisions expanding collaboration with national laboratories as a crucial step in meeting this goal. For example, we are exploring working with Las Alamos National Laboratory to use that site for the pilot application of the risk analysis and visualization model. ESARL similarly is building on our existing relationship with Argonne National Laboratory to leverage opportunities for joint work in the area of technology evaluation and application. We also anticipate continuing to work with CRE to design tools and methodologies that support EM's decision making process. Given our unique and well-established relationships, ESARL also anticipates ongoing collaboration with senior scientific and technical counterparts in the Russian Federation in the areas of risk assessment and technology evaluation.

\subsection{List of Publications and Presentations}

\subsection{Books}

W.A. Rosenbaum, J.L. Regens, eds, The Cold War's Last Legacy: Cambridge, MA, MIT Press, Forthcoming.

Regens, J.L., D.G. Hodges, J.T. Gunter and F.W. Cubbage, Global Warming and Renewable Natural Resource Policy: Pittsburgh, University of Pittsburgh Press, Forthcoming.

Gaddie, R.K. and J.L. Regens, 2000, Regulating Wetlands Protection: Albany, NY, State University of New York Press, $155 \mathrm{p}$. 
Regens, J.L., C.C. Travis, K.R. Obenshain, C.G. Whipple, J.T. Gunter, V. Miller, et al, 1999, Multimedia Modeling and Risk Assessment: South Carolina, The Medical University of South Carolina Press, $170 \mathrm{p}$.

Regens, J.L., D.G. Hodges, P.L. Wilkey, L. Kelley, A.Q. Armstrong, R.E. Zimmerman, et al, 1999, An Integrated Framework for Environmental Technology Evaluation: Application to Subsurface Contaminants: South Carolina, The Medical University of South Carolina Press, 226 p.

\subsection{Chapters in Books}

Luebeck, G., K.H. Watanabe and C.C. Travis, Biologically-Based Models, In G. Zapponi and J. Cogliano, eds., Dose-Response Analysis and Biologically-Based Risk Assessment for Initiator and Promoter Carcinogens: New York, Plenum Press, Forthcoming.

Regens, J.L., P.L. Wilkey, E.A. Hughes, D.G. Hodges, A.Q. Armstrong, L. Kelley, E. Zimmerman, and A.J. Unione, An Integrated Framework for Environmental Technology Evaluation, In Prabhu Dayal, ed., Imnovative Remediation Technologies: Pittsburgh, Air \& Waste Management Association, Forthcoming.

Gunter, J.T., D.G. Hodges and J.L. Regens, 1998, Assessing Present Biological Information for Valuing the Economic Impacts of Climate Change on Softwood Stumpage Supply in the South, In R.A. Mickler and S. Fox, eds. The Productivity and Sustainability of Southern Forest Ecosystems in a Changing Enviromment: New York, Springer-Verlag, p. 795-808.

Hodges, D.G., 1997, A Review of Federal and State Law Affecting the Use of Prescribed Fire for Silvicultural Purposes in the Southern United States, In F. Schmithusen and W. C. Siegel, eds., Developments in Forest and Environmental Law Influencing Natural Resource Management and Forestry Practices in the United States and Canada: Vienna, Austria, IUFRO World Series, Volume 7. International Union of Forestry Research Organizations, p. 162-169.

Rubinstein, A.A., 1997, Micromechanical Approach to Fallure Process in Composites, In B.L. Karihaloo, Y.-W. May, M.I. Ripley, and R.O. Ritchie, eds., Advances in Fracture Research: New York, Pergamon, p. 631-642.

Regens, J.L., 1995, Ecological Risk Assessment: Issues Underlying The Paradigm, In R. Mazaika, R.T. Lackey and S.L. Friant, eds. Ecological Risk Assessment: Use, Abuse, and Alternatives: Amherst, MA, Amherst Scientific Publishers, p. 344-347.

Hodges,D.G. and J.L. Regens, 1994, Biodiversity and Climate Change: Identifying an Economic Research Agenda, In T.J.B. Boyle and C.E.B. Boyle, eds. Biodiversity. Temperate Ecosystems and Global Change: Berlin, Germany, Springer-Verlag, p. 417-428.

Hodges, D.G., K.L. Belli, W.F. Watson, and J.L. Regens, 1994, Forest Policy Implications of Climate Change: Economic Impacts and Potential Mitigation Strategies, In C.V. Mathai and G.L. 
Stensland, eds. Global Climate Change: Science, Policy, and Mitigation Strategies: Pittsburgh, Air and Waste Management Association, p.913-922.

Regens, J.L. and R.W. Rycroft, 1994, The Acid Rain Controversy, In L.D. Guruswamy, et al, eds., International Environmental Law and World Order: St. Paul, MN, West, p. 458-462.

\subsection{Journal Articles}

D.W. Peek and J.L. Regens, Environmental Regulation and International Market Share: The U.S. Chemical Industry's Experience: Technology, Forthcoming.

C.C. Travis, K.R. Obenshain, J.L. Regens, C.G. Whipple, Limitations of Multimedia Models for Use in Envrionmental Decision Making: Environmental Monitoring and Assessment, Forthcoming.

J.L. Regens, B.J. Seldon, E. Elliott, Modeling Compliance to Environmental Regulation: Evidence from Manufacturing Industries: Journal of Policy Modeling, Forthcoming.

I.A. Munn, J.B. Cutshall, and D.G. Hodges, Pulpwood Logging Contractor Survey: Forest Products Journal, Forthcoming.

E. Elliott, B.J. Seldon; and J.L. Regens, Political and Economic Determinants of Individuals' Support for Environmental Spending: Journal of Environmental Management, Forthcoming.

K.H. Watanabe and C.C. Travis, Mathematical Modeling of Skin Papilloma Data in SENCAR Mice: Toxicology and Applied Pharmacology, Forthcoming.

R. Graves and P.N. Pintauro, Polyphosphazene Membranes II. Photo-crosslinking of Poly[(alkyphenoxy)(phenoxy)phosphazene] Films: Journal of Applied Polymer Science, Forthcoming.

R. Ponangi and P.N. Pintauro, Measurement and Interpretation of Equilibrium Organic Vapor Sorption in Polyurethane Membranes: Journal of Membrane Science, Forthcoming.

A.A. Rubinstein, Fracture Anatysis of Composites using Micromechanical Approach: Composites Science and Technology, Forthcoming.

A.A. Rubinstein and P. Wang, The Fracture Toughness of Particle-reinforced Brittle Matrix: Journal of the Mechanics and Physics of Solids, Forthcoming.

Regens, J.L., P.L. Wilkey, R.E. Zimmerman, D.G. Hodges, L.C. Mohr, and G. Fleming, A RiskBased Approach to Setting an Environmental Management Science and Technology Agenda for the U.S. Department of Energy Nuclear Weapons Complex: Environmental Science and Pollution Research, Forthooming.

Regens, J.L., R.E. Zimmerman, P.L. Wilkey, D.G. Hodges, A.Q. Armstrong, and L. Kelley, 
Evaluating Environmental Technology for Meeting Remediation End Points and Long-Term Stewardship Options: Environmental Science and Pollution Research, Forthcoming.

J.L. Regens, D.G. Hodges, L.Kelley, T.A. Sands, Site Remediation Technologies: The Military Engineer, 91(601), pp. 57-58.

J.L. Regens, K.R. Obenshain, C.C. Travis, M. Clauberg, Applying Multimedia Modeling to Karst Systems: Comparing MEPAS, MMSOILS, and RESRAD: Environmental Geosciences, 6(3), pp. 115-122.

J.L. Regens, D.G. Hodges, P.L. Wilkey, L. Kelley, E. Zimmerman, A.Q. Armstrong, L. Kelley, et al, Integrated Framework for Evaluating Subsurface Contamination Remediation Technologies: Environmental Geosciences, 6(2), pp. 82-87.

Regens, J.L., D.G. Hodges, P.L. Wilkey, E. Zimmerman, A.Q. Armstrong, L. Kelley, T.A. Hall, and E.A. Hughes, Screening Technologies for Soil and Groundwater Remediation: Soil \& Groundwater Cleanup, (1999): 24-27.

Regens, J.L., D.G. Hodges, P.L. Wilkey, E. Zimmerman, A.Q. Armstrong, L. Kelley, T.A. Hall, and E.A. Hughes, An Integrated Framework for Evaluating Subsurface Contamination Remediation Technologies: Environmental Geosciences, 6 (1999): 82-89.

X.-Z. Din and E.E. Michaelides, Transport Processes of Water and Protons through Micro-Pores: A.I.Ch.E. Journal, 44 (1998): pp. 35-47.

K.R. Obenshain, M.C. Metcalf, A. Abdelghani, J.L. Regens, D.G. Hodges, and C.M. Swalm, Spatial Analysis of Herbicide Decay Rates in Louisiana: Environmental Monitoring and Assessment, 48 (1997): pp. 307-316.

J.E. Preslan, B. Belkhouche, C.M. Swalm, J.M. Hughes, H. Chen, M. Henry, D. Lin, R.M. Bakeer, A.J. Englande, I. Demtchouk, M.B. Anderson, J.L. Regens, J.C. Means, J.E. Bollinger, L.J. Steinberg, R. Luna, R. Hernandez, W.E. Hartley, and W. J. George, A Database on Water Quality of the Mississippi River: Environmental Progress, 16 (\#3, 1997): pp. 145-163.

Z.-G. Feng and E.E. Michaelides, The Use of Modified Green's Functions in Unsteady Heat Transfer: International Journal of Heat and Mass Transfer, 40 (1997): p. 2997.

Z.-G. Feng and E.E. Michaelides, Unsteady Heat and Mass Transfer from a Spheroid: A.I.Ch.E. Journal, 43 (1997): p. 609.

Z. Bilicki and E.E. Michaelides, Thermodynamic Non-equilibrium in Liquid Vapour Flows: Journal of Non-Equilibrium Thermodynamics, 22 (1997): pp. 99-109.

X.-Z. Din and E.E. Michaelides, Calculation of Long-range Interactions in Molecular Dynamics and Monte Carlo Simulations: Journal of Physical Chemistry A, 101 (1997): pp. 4322-4331. 
X.-Z. Din and E.E. Michaelides, Kinetic Theory and Molecular Dynamics Simulations of Microscopic Flows: Physics of Fluids, 9 (1997): pp. 3015-3025.

Z. Bilicki, R. Kwidzinski and E.E. Michaelides, Effect of Mechanical Non-Equilibrium on Dissipation in condensing Bubbly Flow: Archives of Themodynamics, 17 (1997): pp 25-33.

K. Jian and P.N. Pintauro, Asymmetric PVDF Hollow Fiber Membranes for Organic/Water Pervaporation Separations: Journal of Membrane Science, 135 (1997): pp. 41-53.

Y. Yang, J. Walz, and P.N. Pintauro, Curvature Effects on Electric Double Layer Forces II. Dependence of Forces on the Dielectric Constant: Journal of the Chemical Society, Faraday Transactions, 93 (1997): pp. 603-611.

R. Tandon and P.N. Pintauro, Divalent/Monovalent Cation Uptake Selectivity in a Nafion CationExchange Membrane: Journal of Membrane Science, 136 (1997): pp 207-219.

J.L. Regens and D.G. Hodges, Perspectives on Valuing Forest Ecosystem Health: Ecosystem Health, 2 (March 1996): pp. 3-4.

D.G. Hodges and J.L. Regens, Methodological Issues in Valuing Forest Ecosystem Health: Ecosystem Health, 2 (March 1996): pp. 52-55.

K.H. Watanabe and F.Y. Bois, Interspecies Extrapolation of Physiological Pharmacokinetic Parameter Distributions: Risk Analysis, 16 (1996): pp. 741-754.

J.L. Regens, Ecological Risk Assessment: Issues Underlying the Paradigm: Human \& Ecological Risk Assessment, 1 (\#4, 1995): pp. 344-347.

E. Elliott, J.L. Regens and B.J. Seldon, Exploring Variation in Support for Environmental Protection: Social Science Quarterly, 76 (March 1995): pp. 41-52.

B.J: Seldon, E. Elliott, J.L. Regens and C.G. Hunter, The Effect of EPA Enforcement on Private Sector Pollution Control Investment: Applied Economics, 26 (1994): pp. 949-955.

\subsection{Presentations}

J.T. Gunter, D.G. Hodges, C.M. Swalm, and J.L. Regens, Impact of Urbanization on Timber Availability: A GIS Application: at the 1999 ESRI User Conference, San Diego Convention Center, San Diego, California, July 26-30,1999.

J.T. Gunter, D.G. Hodges, C.M. Swalm, and J.L. Regens, Impact of Urbanization on Timber Availability: A GIS Application: at the 15th Annual Louisiana Remote Sensing \& Geographic Information Systems Workshop, Lafayette, Louisiana, April 13-15, 1999.

J.L. Regens, D.G. Hodges, P.L.Wilkey, R.E. Zimmerman, L.C. Mohr, G. Flemming, A Risk-Based 
.Approach for Evaluating! 'nce and Technology Priorities for En nmental Management at the U.S. Department of Energy I vuclear Weapons Complex: at the 2nd IS \& C/SAC Seminar "Large Scale Area Remediation: Snezhinsk, Russia. June 21-25, 1999.

Zimmerman, R.E., J.L. Regens, P.L. Wilkey, Multiparametric Tool for Evaluation of the Development and Deployment of Innovative Remediation Technologies: at the 2nd ISTC/SAC Seminar "Large Scale Area Remediation: Snezhinsk, Russia. June 21-25, 1999.

J.L. Regens, K.R. Obenshain, C.Travis, J.T. Gunter, V.Miller, Multimedia modeling of environmental restoration risks at Rocky Flats: at the Waste Management 99, Tucson, Arizonia. February 28 - March 4, 1999.

D.G. Hodges, J.T. Gunter, C.M. Swalm, and J.L.Regens, Evaluating the natural resource impacts of growth and development in St. Tammany Parish: at the Louisiana State of the State Conference, Baton Rouge. November 15, 1998.

D.G. Hodges, J.L. Regens, C.M. Swalm, and J.T. Gunter, Impact of Urbanization and Environmental Protection Policies on Timber Availability: A GIS Example: at the Geospatial Information in Agriculture and Forestry Conference, Lake Buena Vista, Florida, June 1-3, 1998.

D. G. Hodges, J.T. Gunter, C.M. Swalm, and J.L. Regens, Utilizing GIS to Assess the Impact of Urbanization on Timber Availability in Southeastern Louisiana: at the SORFOR GIS '98 Workshop, Athens, Georgia, October 26-29, 1998.

C. Brown, A. Dicko, M. Bogayoko, S. Doumbia, D. Mokadam, J.L. Regens, Y.T. Toure, D.G. Hodges, O. Doumbo, and D.J. Krogstad, Mapping the Risk of Severe Malaria in Bancoumana, Mali: GIS Methods for Studying Severe Malaria at the Village Level: at the GIS in Public Health 3rd National Conference, San Diego, August 18-20, 1998.

M. Clauberg and J.L. Regens, Comparison of Multi-Media Model Results of the Consortium for Environmental Risk Evaluation: at the European Commission International Workshop on Risk Assessment Models and Risk Management for Contaminated Sites, Berlin, Germany, April 23-24, 1998.

D. Mokadam, J.T. Gunter, J. Burnam, C.M. Swalm, D.G. Hodges, and J.L. Regens, $A$ Method for Digitizing Soils of St. Tammany Parish Using Arc/Info and Natural Resource Conservation Service (NRCS) Soil Survey Maps: at the the 14th Annual Louisiana Remote Sensing and Geographic Information Systems Workshop, Layfayette, Louisiana, April 7-9, 1998.

C.M. Swalm, J.T. Gunter, J.L. Regens, and D.G. Hodges, Using GIS to Integrate Data for Water Quality Assessment of the Lower Mississippi River: at the Annual Meeting of the Association of American Geographers, Boston, March 25-29, 1998.

J.L. Regens, D.G. Hodges, P. Wilkey, L. Kelley, A. Armstrong, E. Zimmerman, T.A. Hall, and E.A. Hughes, Integrated Framework for Assessment of Site Remediation Options: at the Waste 
Management 98 Symposium, Tucson, March 1-5, 1998.

O.A. Pimenov and E.E. Michealides, Radionuclide Dispersion from Forest Fires: at the 5th Environmental Sciences Symposium, Molyvos, Greece, 1997.

C. Swalm, J.T. Gunter, J.L. Regens, and D.G. Hodges, Integration of Historical and Current Data to Assess Mississippi River Water Quality from South of Memphis to the Gulf Outlet at Southwest Pass: at the the 17th Ammual ESRI Users Conference, San Diego, July 8-11, 1997.

S.C. Das and S.H. Aung, Local Buckling of Tall and Thin-Walled High-Strength Concrete Box Piers: at the the 4th International Conference on Composite Engineering, Honolulu, Hawaii, July 6-7, 1997.

J.L. Regens, D.G. Hodges, P. Wilkey, E.A. Hughes, E. Zimmerman, and A. Unione, An Integrated Framework for Environmental Technology Evaluation: at the Ammual Meeting of the Air and Waste Management Association, Toronto, Canada, June 8-13, 1997.

G.A. Sharovarov, I.I. Matveenko, E.E. Michaelides, O.H. Shakov, and V.G. Molotych, The Migration of Radionuclides in Belarus and the Prognosis for the Future: at the the IAEA One Decade After Chernobyl Conference, Kiev, Ukraine, 1997.

A.A. Rubinstein, Micromechanical Approach to Failure Process in Composites: at the 9th International Conference on Fracture, Sydney, Australia, 1997.

O. Melkozerova, E.E. Michaelides, O. Zhukova, and A. Brenkert, Fate and Transport of radionuclides in Aquatic Environments following the Chernobyl Accident: at the Flowers-97 Conference, Florence, Italy, 1997.

I.A. Mum, D.G. Hodges, and T.C. Truitt, Determinants of Research and Development Expenditures in the Forest Products Industry: at the Southern Forest Economics Workshop, Little Rock, Arkansas, March 20, 1997.

J.L. Regens, P. Wilkey, E.A. Hughes, D.G. Hodges, E. Zimmerman, and A. Unione, An Analytical Framework for Assessing Environmental Technology Applications at U.S. Department of Energy Sites: at the Waste Management 97 Symposium, Tucson, March 2-6, 1997.

J.L. Regens, C. Whipple, C. Travis, D. Hoel, G. Chieruzzi, and K. Watanabe, Multimedia Risk Model Comparison for Environmental Restoration: at the Waste Management 97 Symposium, Tucson, March 2-6, 1997.

E.E. Michealides, Analogies in the Momentum and Energy Equations of Particles: at the ASME FED-97 Conference, Vancouver, Canada, 1997.

S.C. Das, W.W. St. Cyr, G.A. Pitalo, and E.P. Russo, Dynamic Responses of NASA Stennis Space Center Test Stand Diffuser Under Acoustic Medium: at the the 11th Intersociety Cryogenic 
Symposium Energy Week Conference, Houston, January 28-30, 1997.

J.L. Regens, Tools for Informing Environmental Management: at the Annual Meeting of the Society for Risk Analysis, New Orleans, December 8-12, 1996.

R.K. Johnson, J.L. Regens, D.G. Hodges, C. Brown and J.T. Gunter, Spatial Analysis of Congenital Heart Disease in Louisiana: at the Annual Meeting of the American Public Health Association, New York, November 17-21, 1996.

K.H. Watanabe, J.L. Regens, D.G. Hodges, R.K. Johnson and C.M. Swalm, The Application of Ecological Modeling to Assess the Bioaccumulation of Contaminants in an Aquatic Ecosystem: at the EcoSummit 96, Copenhagen, Denmark, August 19-23, 1996.

J.T. Gunter, C.M. Swalm, D.G. Hodges, and J.L. Regens, The Influence of Streamside Land Use on Water Quality in the Louisiana Delta: at the Delta Sustainable Natural Resources Conference, Memphis, Temnessee, August 13-16, 1996.

S.C. Das and X. Zhang, Parametric Sensittvity Study of Nonlinear Buckling of Reinforced Concrete Panels by Finite Element Method: at the 3rd International Conference on Composite Engineering, New Orleans, July 21-26, 1996.

D.G. Hodges and J.L. Regens, Forest Management Mitigation of CO2 Emissions: Assessing the Physical Risk: at the Annual Meeting of the Air and Waste Management Association, Nashville, June 23-28, 1996.

J.L. Regens, R.K. Johnson, C. Brown, C.M. Swalm, and D.G. Hodges, Tracking the Incidence of Pediatric Coronary Disease: at the ESRI Users' Conference, Palm Springs, California, May 20-24, 1996.

K.H. Watanabe, J.L. Regens, D.G. Hodges, R.K. Johnson, and C.M. Swalm, Evaluating the Bioaccumulation of Heavy Metals and Organics in an Aquatic Environment: at the HSRC/WERC Joint Conference on the Environment, Albuquerque, New Mexico, May 21-23, 1996.

J.L. Regens, K.H. Watanabe, D.G. Hodges, R.K. Johnson, and C.M. Swalm, Monitoring Bioaccumulation of Heavy Metals and Organics in an Aquatic Ecosystem: at the International Conference on Application of Geographic Information Systems in Hydrology and Water Resource Management, Vienna, Austria, April 16-19, 1996.

J.L. Regens, K.H. Watanabe, R.K. Johnson, C.M. Swalm, and S. Davis-Nelson, Visual Summarization of Data Using GIS for Devil's Swamp: at the 12th Amual Louisiana Remote Sensing and Geographic Information Systems Workshop, Lafayette, April 16-18, 1996.

J.L. Regens and D.G. Hodges, GIS and Remote Sensing Applications to Evaluate Public Health Effects of Global Warming: at the 7th International Global Warming International Conference, ienna, Austria, April 1-3, 1996. 
J.L. Regens, D.G. Hodges, J.T. Gunter, C.M. Swalm, and C. Brown, Assessing the Impacts of Land Use Change on Local Economic Patterns: at the 26th Symposium on Remote Sensing of Environment and 18th Symposium of the Canadian Remote Sensing Society, Vancouver, Canada, March 25-29, 1996.

J.T. Gunter, J.L. Regens, D.G. Hodges, K.R. Obenshain, and C.M. Swalm,, Spatial Variation in Land Use Impacts on the Sustainability of Water Quality: at the Conference on Geographical Information Systems in Environmental Resource Management, Reno, Nevada, March 13-15, 1996.

K.R. Obenshain, M.C. Metcalf, A.A. Abdelghani, J.L. Regens, D.G. Hodges, and C.M. Swalm, Spatial Analysis of Pesticide Decay Rates in Louisiana: at the Conference on Geographical Information Systems in Environmental Resource Management, Reno, Nevada, March 13-15, 1996.

J.L. Regens and D.W North, Health and Ecological Risks at the U.S. Department of Energy's Nuclear Weapons Complex: Lessons from the CERE Program: at the Annual Meeting of the Society for Risk Analysis, Honolulu, December 3-6, 1995.

J.L. Regens, E. Elliott, and B. Seldon, Modeling the Compliance Costs of Environmental Regulation: The Determinants of Manufacturing Industries' Expenditures for Pollution Control: at the Annual Meeting of the Atlantic Economic Society, Williamsburg, Virginia, October 8-11, 1995.

J.L. Regens, Ecological Risk Assessment: Issues Underlying the Paradigm: at the (Keynote) Symposium on Ecological Risk Assessment: Use, Abuse and Alternatives, Corvallis, Oregon, November 15-16, 1994.

D.G. Hodges and J.L. Regens, Valuing Forest Ecosystem Health: at the Annual Meeting of the Society of American Foresters, Anchorage, Alaska, September 18-21, 1994.

J.L. Regens and D.G. Hodges, Theoretical Basis for Valuing Ecosystem Health: at the First International Symposium on Ecosystem Health and Medicine, Ottawa, Canada, June 19-23, 1994.

D.G. Hodges, J.L. Regens, K.L. Belli, and W.F. Watson, Forest Policy Implications of Climate Change: Economic Impacts and Potential Mitigation Strategies: at the International Specialty Conference on Global Climate Change, Phoenix, April 5-8, 1994.

D.G. Hodges, J.T. Gunter, and J.L. Regens, The Value of Biophysical Information for Assessing the Economic Impacts of Global Climate Change: at the Annual Meeting of the Southern Forest Economic Workers Association, Savannah, Georgia, March 27-29, 1994.

D.G. Hodges, J.L. Regens, and J.T. Gunter, Appraising the Impact of the Uncertainty of Biological Responses to Climate Change on Economic Valuation: at the Annual Meeting of the U.S. Forest Service Southern Global Change Program, New Orleans, March 1-3, 1994.

J.L. Regens, L. White, B.J. Albers, and C. Purdy, Geomatic Techniques for Assessing Ecological and 
Health Risk at U.S. Department of Energy Facilities: at the Waste Management 94 Symposium, Tucson, February 27-March 3, 1994.

\subsection{Proceedings}

J.T. Gunter, D.G. Hodges, C.M. Swalm, and J.L. Regens, Impact of Urbanization on Timer Availability: A GIS Application: In Proceedings of the 1999 ESRI User Conference, San Diego Convention Cente, San Diego, California, Forthcoming.

I.A. Munn, D.G. Hodges,T.C. Truitt, Determinants of Research and Development Expenditures in the Forest Products Industry: In Proceedings of the 1997 Southern Forest Economics Workshop, Forthcoming.

J.L. Regens, D.G. Hodges, P.L.Wilkey, R.E. Zimmerman, L.C. Mohr, G. Flemming, A Risk-based Approach for Evaluating Science and Technology Priorities for Environmental Management at the U.S. Department of Energy Nuclear Weapons Complex: In Proceedings of the 2nd ISTC/SAC Seminar "Large Scale Area Remediation, Snezhinsk, Russia,1999, pp. 3.1-3.6.

Zimmerman, R.E., J.L. Regens, P.L. Wilkey, Multiparametric Tool for Evaluation of the Development and Deployment of Innovative Remediation Technologies: In Proceedings of the 2nd ISTC/SAC Seminar "Large Scale Area Remediation, Snezhinsk, Russia,1999, pp. 5.1-5.10.

D.G. Hodges, J.T. Gunter, C.M. Swalm, and J.L. Regens, Assessing the impact of urbanization on timberland availability in southeastern Louisiana: In Proceedings of the 28th Annual Southern Forest Economics Workshop, Biloxi, Mississippi.

D.G. Hodges, J.T. Gunter, C.M. Swalm, and J.L. Regens, Utilizing GIS to Assess the Impact of Urbanization on Timber Availability in Southeastern Louisiana: In H. J-H Whiffen and W.C. Hubbard (eds.): Proceedings, SOFOR GIS '98, 2nd Southern Forestry GIS Conference, Daniel B. Warnell School of Forest Resources. Athens, GA., pp. 285-302.

D.G. Hodges, J.T. Gunter, C.M. Swalm, and J.L. Regens, Utilizing GIS to assess the impact of urbanization on timberland availability in southeastern Louisiana: In Proceedings, First International Conference on Geospatial Information in Agriculture and Forestry, Rime International, Inc., Ann Arbor, MI. Volume 1, pp. 413-420.

M. Clauberg and J.L. Regens, Comparison of Multi-Media Model Results of the Consortium for Environmental Risk Evaluation: In A. Troge, ed., Proceedings of the Concerted Action for Contaminated Sites in the European Union International Workshop on Risk Assessment Models and Risk Management for Contaminated Sites, Berlin, Germany: Federal Ministry for the Enviromment, Nature Conservation and Nuclear Safety, 1998, pp.121-131.

C.M. Swalm, J.T. Gunter, J.L. Regens, and D.G. Hodges, Integration of Historical and Current Data to Assess Mississippi River Water Quality from South of Memphis to the Gulf Outlet at Southwest Pass: In L. Durant, R.A. Thomas, and P.J. Thomas, eds., Proceedings of the 1997 Louisiana 